\title{
DIFFERING FEDERAI AND STATE INTERPRETA- TIONS OF THE TRANSFER INHERITANCE TAX APPLIED TO TRUSTS INTER VIVOS
}

\section{LOUIS BARCROFT RUNK \\ INTRODUCTION}

To any one interested in the comparative study of legal decisions, it is intensely intriguing to take a statute which has been passed in substantially similar form in several jurisdictions, and compare the interpretations put upon it by different groups of judges, each group supreme within its own jurisdiction. The question becomes doubly interesting where these judges put different interpretations upon the same language. Such a situation is presented by the construction placed by the federal courts and by most of the state courts, so far as decisions have been made, on similar language in the Federal Tax Act and in the Transfer Inheritance Tax Acts of some of the states, regarding the taxation of certain kinds of trust estates created by deed during the settlor's lifetime. This article is concerned primarily with these differences in interpretation in the state of Pennsylvania, with the addition of certain typical illustrative decisions in some of the other states that have been rendered in the last ten years.

The Federal Revenue Act of September 8, I9I6, ${ }^{1}$ provided for the taxation of any trust estate created at any time before the settlor's death, where it was "intended to take effect in possession or enjoyment at or after his death". This phraseology was not original with the Congress of 1916 -it had been used in Pennsylvania as early as the Act of April 7, 1826, Section ${ }^{2}{ }^{2}$ passed over ninety years previously.

The success of the Federal Government as a tax collector from the estates of decedents during the war and in the years immediately following it led the legislatures of various states to recast their own inheritance tax statutes, and to enact new ones embodying at least some of the phraseology that was new in the

139 STAT. 756 (I916).

2 Laws of PenNa., I825-1826, c. LXXII. 
Federal Act. This was the case in Pennsylvania, where an Inheritance Tax Act was adopted in I919. ${ }^{3}$ This generally codified, redefined and enlarged the scope of the earlier acts and also provided for a direct inheritance transfer tax, retaining, with the addition of the word 'gift' this same language of the earlier act as to transfers "by deed, grant, bargain, sale or gift . . . intended to take effect in possession or enjoyment at or after . . . death".

The differences in interpretation we are here considering result in the divergent tests of taxability adopted by the state and federal courts, the former placing emphasis on the parties entitled to the income, the latter on the revocability of such trusts. With these two aspects in view four possible combinations of facts present themselves, omitting all transfers made in contemplation of death:

A. The settlor reserving the right to revoke and also all or most of the income to himself for life.

B. The settlor reserving a general right to revoke but with the income payable to others during their lives.

C. The trust irrevocable and the settlor reserving all the income for life.

D. The trust irrevocable with the income payable to others for their lives.

Each of these four may also have annexed to it a power of appointment as to the remainder, and this remainder interest may, under certain contingencies in irrevocable trusts, revert back to the settlor's own estate.

A. The Settion Reserving the Right to Revoke, and Aiso All or Most of the Income to Himself for Life

Here the great weight of state and federal authority holds the trust estate taxable at the death of the settlor as part of his own estate. For Pennsylvania, Lines' Estate ${ }^{4}$ and the more recent application of the principle in Hartley's Estate ${ }^{5}$ may be cited.

${ }^{3}$ Act of June 20,1919, P. L. 521 .

I55 Pa. 378, 26 At1. 728 (1893).

${ }^{\circ} 8$ D. \& C. $164(\mathrm{~Pa}, 1926)$. 
Representative cases similar to these can also be found in Illinois, ${ }^{5}$ Massachusetts, ${ }^{7}$ Nebraska, ${ }^{8}$ Nevada, ${ }^{9}$ New York, ${ }^{10}$ North Carolina, ${ }^{11}$ Vermont, ${ }^{12}$ Oregon and Wisconsin $;^{13}$ a typical federal case is United States $v$. Stark. ${ }^{14}$ Of course, a reservation of power to appoint the principal makes the argument for taxation even stronger; this was laid down nearly seventy years ago in Pennsylvania ${ }^{15}$ and is illustrated by a recent case in California. ${ }^{16}$ The United States Supreme Court, in Bullen v. Wisconsin, ${ }^{17}$ decided that a power of appointment reserved by the donor leaves the transfer, as to him, incomplete and subject to tax. And as general powers of appointment are specifically taxed by the federal statutes, no decisions as to the federal tax on them are needed here. To this general rule of taxability, Connecticut ${ }^{18}$ and possibly Maryland ${ }^{19}$ seem outstanding exceptions.

\section{B. The Settior Reserving a General Right to Revoke but With the Income Payable to Others During Their LIVES}

The leading state case on this seems to be Dolan's Eistate, ${ }^{20}$ decided in I924 by the Supreme Court of Pennsylvania. Here a settlor had executed a deed of trust in 1908, transferring certain

- People v. McCormick, 327 Ill. 547, I 58 N. E. 86I (1927).

"Saltonstall v. Treasurer, et al., 256 Mass. 519, I53 N. E. 4 (I926) ; aff'd by the U. S. Supreme Ct. in 276 U. S. 260, 271, 48 Sup. Ct. 225, 227 (1928).

${ }^{8}$ Bronzynski's Est., 116 Neb. 196, 216 N. W. 558 (1927).

' Miller's Est., 43 Nev. 12, 177 Pac. 409 (1919).

${ }^{10}$ In re Bostwick, I60 N. Y. 489,55 N. E. 208 ( 1899 ), criticising and limiting Masury's Est., 28 App. Div. 580, $5 \mathrm{I} \mathrm{N}$. $\dot{Y}$. Supp. 33I, which was affirmed without opinion in 159 N. Y. 532, 53 N. E. II27 (1899). Dana Co., 215 N. Y. $46 \mathrm{r}, 109$ N. E. 557 (1915).

${ }^{11}$ Bank v. Doughton, I88 N. C. 762 , I25 S. E. 621 (1924).

${ }^{12}$ Fulham's Est., 96 Vt. 308, i 9 Atl. 433 (1923).

${ }^{23}$ Wallace's Est., 131 Ore. 597, 282 Pac. 760 (1929); Warsco v. Oshkosh, 183 Wis. 156,196 N. W. 829 (1924).

14 32 F. (2d) 453 (C. C. A. 6th, 1929).

13 Wright's Appeal, $38 \mathrm{~Pa} .507$ (I86r).

${ }^{15}$ Murphy's Est., I82 Cal. 740, I90 Pac. 46 (1920).

${ }^{17} 240$ U. S. 625,36 Sup. Ct. 473 (1916), aff'g 143 Wis. $512,128 \mathrm{~N}$. W. $\log$ (1910). See also Saltonstall v. Treasurer et al., supra note 7. (1929).

${ }^{18}$ Cramer v. Hartford-Connecticut Trust Co., Iro Conn. 22, I47 Atl. 139

${ }_{10}$ Downes v. Safe Deposit \& Trust Co., I57 Md. 87, I45 Atl. 350 (I921). The deed here while in form irrevocable, gave the grantor the right to withdraw $\$ 5000$ per annum of the princioal during his lifetime, if desired.

${ }^{\infty} 279 \mathrm{~Pa} .582$, I24 Atl. 176 (1924) aff'g 3 D. \& C. 264 (Pa. 1923). 
designated securities and any others which she might thereafter deliver, in trust, to be held for twenty-one years after the death of the last surviving lineal descendant of the settlor living at the time of her death, the trustee to pay the income to the settlor's three male children during their lives, and after their deaths to their widows during widowhood, then to their issue living at the expiration of the twenty-one-year period above mentioned. Under the trust, the settlor, or the majority of the beneficiaries, could remove the trustee at any time, and the settlor had the right to revoke the trust in its entirety at any time during her life, or from time to time to alter or amend it.

Before the settlor died the Direct Inheritance Tax Act ${ }^{21}$ had been enacted, and the life estates of the sons were appraised and taxed. The Orphans' Court, on appeal from the Register, held that the property had vested prior to the passage of the Act, which imposed the tax, and that no tax was due. This decision was affirmed by the Pennsylvania Supreme Court. In its opinion the Court stated that a conveyance must part with "possession, title and enjoyment in the grantor's lifetime" to escape taxation, ${ }^{22}$ and that when a settlor retained the "grasp" of the entire estate as long as he lived, it could not be said that possession and enjoyment in the beneficiaries took effect prior to death; in such a case, the Commonwealth was entitled to a tax on the transfer. They further stated, however, that this case was distinguishable, as the settlor had divested herself of the physical control of the property and had given complete and sufficient evidence of the transfer of all ownership. Her death did not change the character of the document or remould it from a deed to a will, and the annexation of a power of revocation did not affect the grantees' power of enjoyment, although the grantees took the estate with the possibility of its being divested by the exercise of the power of revocation. The Court said :

"But the right to revoke, unexercised, is a dead thing. Its presence in a deed does not alter the character of the instrument or estate granted; to all intents and purposes, title and

"Supra note 3 .

2 Citing Reish v. Commonwealth, ro6 Pa. 521, 526 (1884). 
possession pass just as effectively as any deed or grant could make it, continuing in that state so long as the power of revocation lies dormant." 23

A power of revocation unexercised was compared to an unexercised power of appointment.

When the Court decided Dolan's Estate, it had precedents from two other states to follow, ${ }^{24}$ and it also cited its own cases allowing either husband or wife to set up a trust for himself or herself with power of revocation, without rendering the deed a testamentary instrument. ${ }^{25}$ It also relied on some general statements from the opinion of the United States Supreme Court in Jones $v$ Clifton, ${ }^{26}$ as delivered by Mr. Justice Field in 1879 . In this case Clifton had married in 1870 . Two years later he gave his wife by a recorded deed, to hold as a separate estate, a parcel of land and five insurance policies on his life, rèserving to himself a power to revoke, grant and assign the same in whole or in part, and to transfer the property to any uses he might appoint. The next year he gave his wife under a similar recorded deed two other parcels of land. At the time these transfers were made he was worth more than fifty thousand dollars. The panic of 1873 and his bad management made him an insolvent in 1875 , and his assignee in bankruptcy sued to set aside these two deeds and compel a transfer. It was held that these were voluntary settlements upon his wife, made when free from debt, and were valid, Justice Field saying in the opinion:

"The powers of revocation and appointment to other uses reserved to the husband in the deeds in question do not impair their validity or their efficiency in transferring the estate to the wife to be held by her until such revocation or appointment be made. Indeed such reservations are usual in family settlements and are intended 'to meet the ever varying interests of family connections'. Riggs v. Murray, 2 Johns (N. Y.) Ch. 565 . . . the absence of a power of revoca-

${ }^{23} 279 \mathrm{~Pa}$ at 589 , I24 Atl. at 178.

2 People v. Northern Trust Co., 289 I1l. 475, 124 N. E. 662 (I920) ; Masury's Est., supra note ro.

${ }^{z}$ Lines v. Lines, I42 Pa. I49, 2I Atl. 809 (I89I) ; Windolph v. Girard Trust Co., 245 Pa. 349, 9I Atl. 634 (I9I4).

${ }^{28}$ IOI U. S. 225, 230 (1879). 
tion and of appointment to other uses in a deed of family settlement has often been considered a badge of fraud and except when made solely to guard against the extravagance and imprudence of the settlor, such settlements have in many instances been annulled on that ground."

The Court further remarked that these settlements with such powers of revocation attached were "of greater importance" in England than in America.

The test of whether the deeds of trust belong to the first class and are taxable or to the second class under which they are generally held non-taxable in the state courts was thus stated in I923, by Judge (now Chief Justice) Cardozo of the New York Court of Appeals :

"The distinction is between a gift which clothes the donee with a right of present enjoyment, though subject to revocation at the will of the donor, and one where the donor reserves to himself not only the power to revoke, but also enjoyment during life, so that no beneficial right enforcible against him exists until his death. In the one class of cases, the law in force at the delivery of the deed, and in the other the law in force at death, is the measure of the right to tax." 27

The New York decisions stress the word "intend" in the statute, $i$. $e$., the intention existing at the moment the trust was created:

"What did the donor intend as to the possession, or the enjoyment of the avails of the gift in the instant case? Did he intend the gifts to take effect in possession or enjoyment at or after death? Did the donees have such possession or enjoyment from the creation of the trusts?"

If the donor intended the objects of his bounty (excluding himself) to have the enjoyment of the property during his life, it is obvious that he did not 'intend' to have their enjoyment of his bounty postponed until his death.

Some of the other states, in addition to New York, which have construed these words in the same manner as the Pennsyl-

${ }^{27}$ Matter of Schmidlapp, 236 N. Y. 278, 284, 140 N. E. 697 (1923). See also Cochrane's Estate, II7 Misc. I8, I90 N. Y. Supp. 895 (192I), aff'd without opinion 202 App. Div. 75I, I94 N. Y. Supp. 924 (x922). 
vania Court in Dolan's Estate, and have thus relieved the estate transferred from transfer tax, are Illinois ${ }^{28}$ and Massachusetts. ${ }^{29}$

The federal judges, however, when they came to construe this same statutory language, $i$. e., "intended to take effect in possession or enjoyment at or after death", decided that the ability to get the property back was equivalent to potential enjoyment, even if this right was not exercised; as the donor had at all times the right and power to repossess himself, even if he did not do so, it was potentially his and as such should be taxed under the Federal Revenue Act. They placed the emphasis on the word 'transfer'. This conclusion seems to follow from the language of the Court in two cases handed down the same day-January 8, I929, although each case, if rested only on its own facts, would not seem to justify such a broad general rule, so far as the present decisions of the United States Supreme Court are concerned. These cases are Chase National Bank v. the United States ${ }^{30}$ and Reineke v. The Trust Company. ${ }^{31}$ The Chase case covered only insurance policies, which our state statutes and decisions would have exempted from the state tax, but the language of the Court is important:

“. . . the word 'transfer' . . . cannot be taken in such a restricted sense as to refer only to the passing of particular items of property directly from the decedent to the transferee. . . . Termination of the power of control at the time of death . . . brings about at death the completion of that shifting of the economic benefits of property which is the real subject of the tax, just as effectively as would its exercise. . . . To make a decision between a general power and a limitation in fee is to grasp at a shadow while the substance escapes. Sugden on Powers, 8th Ed. 396."

${ }^{2}$ People v. Northern Trust Co., supra note 24; People v. Northern Trust Co., 330 Ill. 238, 16I N. E. 525 (I928) (as to two of the four deeds).

$\approx$ Dexter v. Treasurer and Receiver General, 243 Mass. 523, I37 N. E. 877 (I923). See also Bower's Est, I95 App. Div. 548, I86 N. Y. Supp. 912 (Ig2I), rev'g I83 N. Y. Supp. I37, aff'd without opinion, 23I N. Y. 6I3 (I92I). Miller's Est, 204 App. Div. 4I8, I98 N. Y. Supp. 202 (I923) as modified in 236 N. Y. 290,140 N. E. 70I (I923), and 237 N. Y. 524,143 N. E. 728 (I923); Cochrane's Est., supra note 27; Carnegie Est., II7 Misc. 806, I9I N. Y. Supp. 753 (I921), aff'd in 236 N. Y. 517 , 142 N. E. 266 (I923).

${ }^{30} 278$ U. S. $327,337,338,49$ Sup. Ct. I26, I28.

${ }^{32}$ Ibid. at 339, 49 Sup. Ct. at I23. 
In the Reineke case," "respondent's testator died May 30, I922. On various dates between I903 and I9I9 he established seven trusts by deed which are conceded not to have been in contemplation of death. Two of them were created respectively in 1903 and I9Io. They are . . . referred to here as the 'two trusts'. By them the income from the trusts was reserved to the settlor for life and on his death the income of each trust was to be paid to a designated person until the termination of the trust as provided in the trust instrument, with remainders over. By the terms of each trust there was reserved to the settlor alone a power of revocation of the trusts, upon the exercise of which the trustee was required to return the corpus of the trust to him.

"The remaining five trusts, . . . referred to here as the 'five trusts', were created in I9I9 before the passage of the Revenue Act of I92I, but after the enactment of the similar provisions of the estate tax of the Revenue Act of r918. ${ }^{33}$ By each, life interests in the income, on terms not now important, were created. In one the life interest was terminable five years after the death of the settlor or on the death of the designated life beneficiary should she survive that date, with a remainder over. In the other four, life interests in the income were created, terminable five years after the settlor's death or on the death of the respective life tenants, whichever should first happen, with remainders over. The settlor reserved to himself power to supervise the reinvestment of trust funds, to require the trustee to execute proxies to his nominee, to vote any shares of stock held by the trustee, to control all leases executed by the trustee, and to appoint successor trustees. With respect to each of these five trusts a power was also reserved 'to alter, change or modify the trust,' which was to be exercised in the case of four of them by the settlor and the single beneficiary of each trust, acting jointly, and in the case of one of the trusts, by the settlor and a majority of the beneficiaries named, acting jointly.

"The settlor died without having revoked either of the two trusts and with the beneficiaries and life tenants designated in the

\footnotetext{
s The following statement of facts is from the opinion of Mr. Justice Stone, ibid. at 343,49 Sup. Ct. at I24.

${ }^{*} 40$ STAT. Iog6, I097, 26 U. S. C. A. $\S$ rogr, I0g2 (Ig28).
} 
trusts surviving him, and without having modified any of the five trusts except one and that in a manner not now material." The Court, citing the Chase case, held the two trusts taxable. The other five, where the power of revocation could only be exercised with the consent of the beneficiaries, were held not taxable.

The Court, however, logically carried out the full implications of its language in the Chase case, ${ }^{34}$ in Corliss $v$. Bowers, ${ }^{35}$ decided in r930, and held that under the income clause of the Federal Acts, in a revocable trust with income to a wife for life and remainder to the children, the settlor must pay the income tax himself, since the wife's acquisition of the income becomes complete only when the settlor fails to exercise the power that he has reserved.

In a recent $U$. S. District Court case, ${ }^{36}$ a reserved right to change the trust and trustee and name other beneficiaries except the settlor was held to make the corpus taxable. But if the reserved power of appointment is only special and not general, no tax is due, as only general powers of appointment come under the language of the Federal Act. ${ }^{37}$ As might be expected, Dolan's Estate is in direct opposition to a later case in the Circuit Court of Appeals ${ }^{38}$ for that circuit, where an unsuccessful effort was made by the settlor's executors to recover the federal tax that had been paid.

While these federal cases are apparently not in harmony with some expressions as above cited in Jones v. Clifton, decided over fifty years ago, it is to be remembered that a marriage settlement, made by a man when solvent and later attacked by his creditors, was involved in that case; the statements of law in it will be doubtless held only to apply to such type of case, and not to prevent a subsequent federal statute from taxing these modern trusts when they reserve the power of revocation.

\footnotetext{
34 Supra note 30.

${ }^{35} 28$ I U. S. 376,50 Sup. Ct. 336 (1930).

${ }^{20}$ Brady v. Fam, 38 F. (2d) 659 (D. Me. 1930). Also cf. Dean v. Willcuts, 32 F. (2d) 374 (D. Minn. 1929).

${ }^{\mathfrak{T}}$ Farmers L. \& T. Co. v. Bowers, 29 F. (2d) 14 (C. C. A. 2d, I928).

${ }^{23}$ Fidelity Trust Co. v. McCaughan, 34 F. (2d) 443 (C. C. A. 3d, 1920). $C f$. as to irrevocable trusts the contrary decisions as to the identical trust deed in People v. Northern Trust Co., supra note 28 , and Comm'r of Int. Rev. v. Northern Trust Co., infra note 49.
} 
Of course there is much to be said as to the practical wisdom of reaching and taxing such trusts, since it is not strictly true, as was said in Dolan's Estate and others following it, that the "right to revoke unexercised . . . does not alter the character of the . . . estate granted" or "affect the grantee's power of enjoyment". In fact the property right is made to depend on the wish or even the whim and caprice of the settlor, and to that extent vitiates the "enjoyment" of it, which the Reish case ${ }^{39}$ gave as one of the triple tests of absolute ownership. The word "enjoyment" connotes not only "pleasure" but also "satisfaction", and the latter element, which embodies a sense of security against the future, is wanting in a gift that may at any time be recalled; the presence of such a "sword of Damocles" hanging over one's head usually interferes with its unalloyed enjoyment. If the word "enjoyment" means the income now in one's pocket or in one's bank account, one's power of enjoyment of it is not marred by a power of revocation resting in the background unexercised; but if it means an assurance of one's future income from the same source, this assurance is reduced to a more or less complete uncertainty, and depends, perhaps, on whether one has a temperament disposed to worry. The whimsicalities and capricious fancies and illusions of the aged, as shown by many wills made or marriages contracted when senility is approaching, furnish ample proof that this constant dread of what may happen is by no means a groundless fear.

Again, the Dolan opinion loosely compares the right of revocation to a power of appointment, of course when given by some one else and not when reserved in the deed itself, and this resemblance was noted in some of the cases cited; but it is submitted that the differences are greater than the resemblances. Such a power is not over the donee's own property but over that of the donor, the former being merely the conduit pipe to direct the flow of the bounty of the donor of the power; the donee would not in normal course secure the property covered by this kind of a power to himself. On the other hand, a reserved power of revocation in a deed gives the settlor the absolute right to repossess all the

supra note 22. 
property himself as the sole owner at any time, although others have temporarily the usufruct and management of it.

In point of fact the expression in the Reish case, "possession, title and enjoyment in the grantor's lifetime", was only intended, if we take its own facts, to apply to estates which had no power of revocation attached. In that case a man five days before his death conveyed all his property to his brother and took back a bond that he should be given one-half of the net income from the real estate, all the income from the personal property, and should have the free use of his house for the rest of his life. It was held that this transfer was liable to a collateral inheritance tax. Is not this quotation being stretched beyond its reasonable limits when applied, in Dolan's Estate, forty years later, to very changed conditions of modern life and business?

The average man who has made his own money has a naturai reluctance to part with it, partly because he believes he can increase it for his ultimate beneficiaries far faster than any chosen trustee can do in his place, but chiefly because of the consciousness of power that it gives him. Now, if he can retain that power by always keeping in his hand the string that will pull the propertyback into his own exclusive control by a "mere stroke of the pen", it is a tremendous leverage in inducing him to hand over part of his hard-earned fortune to other hands, because he (the settlor) may still retain the consciousness of his power over the actions of his beneficiary. Hence the popularity of the revocable trust, which outstrips the irrevocable kind many times in number and amount. and in so far as the property in it is confined to life insurance policies, as is very often exclusively the case, it would seem in Pennsylvania not only exempt from any possible tax under our various statutes (if the policies are payable to the classes of beneficiaries named in the Acts of Assembly), but secure from the claims of creditors as well. ${ }^{40}$

The New York legislature, feeling that its state courts could not be expected to change their rulings, passed a statute in I922 which taxed all revocable gifts, whether this power to revole, alter

\footnotetext{
${ }^{10}$ Act of April 15, I868, P. L. 103. Act of May 3, 1917, P. L. II2. Act of May 17, I9I9, P、 L. 207. Irving Bank v. Alexander, 280 Pa. 466, 124 Atl. 634 (1924).
} 
or amend can be exercised solely or in conjunction with others. In the vernacular of the average legislator, "he who can shake the plum-tree and during all his life keep those now enjoying its fruit in apprehension lest he diminish their present pleasure or deprive them of it entirely, should ultimately pay a tax in some form for the privilege he has reserved to himself". The act is obviously not retroactive, and so far as is known only the lower courts have thus far construed it.

Revocable deeds of trust are generally not recorded, and the executor or administrator of the estate of a deceased settlor, if different from the trustee under his deed of trust. might very likely in entire good faith never learn of the deeds of trust that had been executed, and therefore would make no return of them to either federal or state taxing authorities; yet the principle embodied in the New York law of 1922 above referred to is likely to be followed and its language enacted in other jurisdictions, since the states will undoubtedly try to reach property, other than insurance policies, transferred under revocable deeds of trust; which run into large sums each year and remove from the reach of the state taxing authorities the very large amounts in cash and securities that they cover.

\section{The Trusts Irrevocable and the Settlor Reserving ALL THE INCOME FOR LIFE}

Here again we note the diverging opinions between the federal courts and those of most of the states as to the liability for transfer inheritance tax. The state courts generally hold the test of such taxability to be whether the settlor himself receives the income; in this event, it naturally makes no difference whether the trust is revocable or irrevocable, except that if irrevocable the date of transfer should determine the amount of the tax, and not the date of death. These principles are illustrated in Pennsylvania by Houston's Estate. ${ }^{42}$ Here an irrevocable deed of trust had been executed in 1918 , the income being paid to the settlor during her

"Schweinert's Est., I33 Misc. 762, 234 N. Y. Supp. 307 (I929) ; Feustman's Est., 240 N. Y. Supp. 403 (1929).

${ }^{2} 276 \mathrm{~Pa} .330$, I20 Atl. 267 (I923), aff'g 2 D. \& C. 334 (Pa. I923). 
life, with remainder over. The settlor died in I92I. The remaindermen were collaterals, and between the date of execution and the date of the death of the settlor, the collateral transfer tax had been raised from $5 \%$ to 10\%. The question was whether this Act of Assembly raised the tax on the remainder. The Court held that under the Act the tax was on the transfer of the title, that the grantor in the deed had parted with her title before the Act raised the rate, that she had neither the right of revocation nor the right of control, and that accordingly the tax should be paid under the old Act which was in force when the transfer of title passed. ${ }^{43}$

Other cases illustrating the principle that an irrevocable trust can be taxed as an inheritance transfer if the settlor has received the income during his life, can be found in Illinois, ${ }^{44}$ Montana, ${ }^{45}$ New Jersey, ${ }^{46}$ New York ${ }^{47}$ and Wisconsin. ${ }^{48}$

The federal courts, however, hold that if the deed is irrevocable it makes no difference if the settlor reserves all the income to himself.49 So, such a trust, created by Mrs. Van Schaick in Illinois, was held not subject to the federal tax after being held subject to taxation in the state; this is just the reverse of the two cases involving Dolan's Estate, which was subject to a federal tax but exempt in Pennsylvania.

One set of jurisdictions stresses the human desire to maintain one's own personal income as large as possible. The other looks at the equally human desire to preserve ultimate power over one's principal as long as possible. With some men the first element is the strongest and with others the second-even in the same man

3 See also Hieskell's Est., 4 D. \& C. 592 (1924).

" People v. Shaffer, 29I Ill. I42, I25 N. E. 887 (1919); also People v. Northern Trust Co., supra note 28.

${ }^{5}$ Schuh's Est., 66 Mont. 50, 212 Pac. 516 (1923).

${ }^{10}$ Congregational Home Miss. Soc. v. Bugbee, IOI N. J. I. 214, I27 Atl. I92 (I925) ; Harvey's Est., I29 Att. 393 (N. J. 1924) ; Farmers Tr. Co. v. Bugbee, I4I Atl. 579 (N. J. 1928) ; Russell's Est, I46 Atl. 36I (N. J. I929).

6 Egerton's Est., IO3 Miso. 47I, I70 N. Y. Supp. 222 (I9I8); Winter's Est., 135 Misc. 258, 237 N. Y. Supp. IOI (I924).

${ }^{4}$ Schrank's Est., 230 N. W. 69I (Wis. I930).

${ }^{19}$ May v. Heiner, 28I U. S. 238, 50 Sup. Ct. 286 (1929); McCaughn v. Carnhill's Exec'r, 43 F. (2d) 69 (C. C. A. 3d, 1930) ; Comm'r of Int. Rev. v. Northern Trust Co., 4I F. (2d) 732 (C. C. A. 7th, 1930); Boyd v. United States, 34 F. (2d) 488 (D. Conn. 1929). But cf. contra Comm'r v. Morsman (C. C. A. 8th) decided Nov. Io, I930, and not yet officially reported. 
at different stages of his health or maturity one element or the other may predominate. Both instincts are deeply rooted in our human nature, and logically there is little to choose between them. We can appreciate the almost genial manner in which Judge Morton of the United States District Court of Massachusetts disposed of the differences in interpretation in deciding a case involving a general power of appointment under another clause of the Federal Act. After admitting that the logic of his state decisions was inescapable, he said, "It was a practical question and Congress had the right to deal with it in a practical way . . . Congress was not absolutely restricted to the legalism of the State courts." 50 Likewise the federal courts have the right to be equally practical in singling out, as the test for taxation, the element of revocability.

D. The Trust Irrevocable With the Income Payarle to OTHERS For Their LIVES

These classes of trusts are believed to be free of tax in all jurisdictions, since the Federal Gift Tax was repealed in $1926 .^{51}$ Illustrative decisions are cited below..$^{52}$

On the other hand, if the principal reverts as a vested remainder to the grantor's estate, it is taxable in New York; ${ }^{53}$ but if this remainder is only contingent, it is apparently not taxable either in Pennsylvania ${ }^{54}$ or in New York $;^{55}$ although seemingly subject to federal tax..$^{\mathbf{6}}$

A mere postponement of the vesting of the title in the beneficiary of a trust agreement until a specified period after death does not destroy irrevocability. ${ }^{57}$

${ }^{50}$ Stratton v. United States, 42 F. (2d) 779 (D. Mass. 1930).

${ }^{52} 44$ STAT. I25 (I926), 26 U. S. C. A. \& I09I, n. (I928).

${ }^{2}$ Reineke v. Trust Co., supra note $3 I$; Hirsh v. United States, 35 F. (2d) 982 (Ct. of Cl. 1929); Williams v. United States, 4I F. (2d) 895 (Ct. of Ci. I920) ; Bronzynski's Est., supra note 8; Cochrane's Est., supra note 27, as to the Getty Trust; Allan v. Hendrick, I04 Ore. 202, 206 Pac. 733 (1922).

${ }^{63}$ Cochrane's Est., N. Y., supre note 27 , as to 5 of the trusts.

"4 Arrison's Est., 8 D. \& C. 494 (1926).

ss Schweinert's Est., supra note $4 \mathrm{I}$. The federal rule is not yet entirely clear. Comm'r v. McCormick, infra note 56; cf. May v. Heiner, supra note 49.

${ }^{50}$ Comm'r v. McCormick, 43 F. (2d) 277 (C. C. A. 7th, 1930), decided Sept. 20 , 1930, and not yet officially reported.

t7 Shukert v. Allen, 273 U. S. 545, 47 Sup. Ct. 46I (I927); Hodgkins Exrs. v. Comm'r (C. C. A. 7th), decided Oct. I6, 1930, and not yet officially reported; People v. No. Trust Co., supra note 38 . 
This federal rule of construction opens a large ficld for men of wealth to get all the income in their estates for their lives and yet ultimately pay no inheritance taxes to the Federal Government. It is of course now only applicable to estates over $\$ 100,000$. But it involves the paying as a price the inability to change any of the beneficiaries of the trust, ${ }^{58}$ and also depriving oneself of the pleasure of ever getting one's principal back. To what extent men of wealth are willing to do this could only be accurately known after the laws have been in operation a long time and after one has accurate figures for the whole country, showing the total amounts held in both revocable and irrevocable trusts by the trust companies.

Moreover the federal tax exemption does not seem incompatible with a settlor retaining some very real rights over the res of the trust estate. Thus in the Reineke case ${ }^{59}$ the settlor reserved the power to supervise investments, to vote stock, to have proxies made to his nominee, to control all leases made and to appoint a successor trustee; and in a recent case in the Superior Court of Pennsylvania it was held that a mere direction that premiums on insurance policies payable to a trustee should be paid out of the income from an irrevocable trust and that the settlor should be consulted on investments; did not constitute "enjoyment" in the settlor so as to make the transfer subject to tax under the Pennsylvania statute. ${ }^{60}$ So, if an irrevocable trust can only be changed with the consent of the trustee, it will not destroy its irrevocability if it is so changed, so as to make it liable to the federal tax, since the trustee of course is responsible to the parties in remainder, and, as said in Erskine v. White, "the trustee is not a rubber stamp".

Now, if a deed is revocable for a fixed period and then becomes irrevocable, what will happen as to the federal tax? It has

ws Bank of New York, Admr. v. Com'r., Board of Tax Appeals, No. 32,88r, opinion Sept. 8, 1930, not yet officially reported.

su Supra note $3 \mathrm{I}$.

${ }^{\infty}$ Logan's Est., opinion July Io, I930, I4 Adv. Super. Unofl. 532.

a U. S. D. C. Mass., opinion Oct. I2, I930, not yet officially reported; also Farmers L. \& T. Co. v. Bowers, Com'r., supra note 37; also Bowers' Est, supra note 29. But compare these with the Saltonstall case, supra note 7, where the right to revoke could only be exercised with the consent of the trustee. and with the recent case of Comm'r v. McCormick, supra note 56. 
been held that the tax becomes payable when it passes from one class to the other, by act of the parties. ${ }^{62}$

So, in conclusion, we can only reiterate that in trusts inter vivos the real basis of liability for state inheritance transfer taxation is "who gets the income?" and in the federal courts the keynote question is whether the trust is revocable, with as many cases close to the dividing line as the ingenuity of counsel and the constant desires of settlors to avoid inheritance or transfer taxes suggest new plans of settlement. If a homely phrase may here be pardoned, everyone wants "both his penny and his cake" if he can get them, and the varying questions that arise under different interpretations by the federal and state courts of identical statutory language in their respective jurisdictions absorb much of the time and add greatly to the professional emoluments of many eminent members of the American bar.

${ }^{2}$ Means v. U. S. (Ct. of C.) H-366, opinion filed Apr. 7, 1930, and not yet officially reported, but certiorari denied by U. S. Supreme Ct. Oct. I3, I930. 